Article

\title{
Anisotropy of Strength and Elastic Properties of Lower Paleozoic Shales from the Baltic Basin, Poland
}

\author{
Przemyslaw Michal Wilczynski *(D), Andrzej Domonik and Pawel Lukaszewski \\ Faculty of Geology, University of Warsaw, Zwirki i Wigury 93 Str., 02-089 Warszawa, Poland; \\ adomonik@uw.edu.pl (A.D.); pawel.lukaszewski@uw.edu.pl (P.L.) \\ * Correspondence: przemyslaw.wilczynski@uw.edu.pl
}

\section{check for} updates

Citation: Wilczynski, P.M.; Domonik, A.; Lukaszewski, P. Anisotropy of Strength and Elastic Properties of Lower Paleozoic Shales from the Baltic Basin, Poland. Energies 2021, 14, 2995. https://doi.org/10.3390/ en14112995

Academic Editors: Dameng Liu, Ruud Weijermars, Tadeusz W. Patzek, Carlos Torres-Verdin and Dongxiao Zhang

Received: 8 April 2021

Accepted: 19 May 2021

Published: 21 May 2021

Publisher's Note: MDPI stays neutral with regard to jurisdictional claims in published maps and institutional affiliations.

Copyright: (c) 2021 by the authors. Licensee MDPI, Basel, Switzerland. This article is an open access article distributed under the terms and conditions of the Creative Commons Attribution (CC BY) license (https:/ / creativecommons.org/licenses/by/ $4.0 /)$.

\begin{abstract}
The paper presents the results of laboratory studies on the strength-strain properties of shales representing four siltstone-claystone lithostratigraphic units occurring in the Baltic Basin. Laboratory studies in a triaxial stress state were conducted as single failure tests on cylindrical samples oriented parallel and perpendicular to lamination within the rocks. Mutually perpendicular samples were cut out from the same drill core sections in order to determine mechanical anisotropy. Samples oriented parallel to lamination were characterised by values of the static Young's modulus twice as high as from samples oriented perpendicular to lamination. Similar variability was observed in the case of maximum differential stress values and Poisson's ratio. Samples parallel to lamination registered notably lower axial strains, which influenced increased values of Young's modulus and Poisson's ratio. The rocks studied are characterised by VTI type (vertical transverse isotropy) internal anisotropy of the rock matrix, which significantly influences the anisotropy of their geomechanical properties.
\end{abstract}

Keywords: shale gas; anisotropy; strength; Young's modulus; Poisson's ratio; Baltic Basin

\section{Introduction}

In the last twenty years, the dynamic development of geomechanics has made a significant contribution to the research field of prospecting and exploitation of unconventional hydrocarbons [1]. Technological development, most notably 3D seismic horizontal drilling and multi-stage hydraulic fracturing, is crucial for successful unconventional gas extraction [2,3]. Geomechanical properties of gas shales have emerged as being critical factors in drilling and production [4,5]. Economic factors are also important during the exploitation of unconventional hydrocarbons. The creation of financial models and the assessment of prices are crucial for the cost-effective exploitation of gas [6]. Challenges related to this development have led to a significant increase in attention to geomechanical models of rock massif [7-10], with these models used more frequently during planning, drilling, and exploration of reservoirs [11].

In shale gas reservoir development, a key step toward optimizing both stimulation and production stages is to evaluate elastic-plastic and visco-elastic-plastic properties, including the detailed treatment of anisotropy and rock strength [12-16], as these influence the success of hydraulic fracturing and fracture response during the stimulation and production stages, respectively [17-20]. Hydraulic fracturing treatments significantly affect the cost of oil and gas extraction from unconventional reservoirs and their global prices. Thus, making decisions on the execution of hydraulic fracturing projects requires a higher level of integration of technical, commercial, and uncertainty analyses [21].

One of the critical aspects of the primary activities in drilling design includes geomechanical studies of rock material in the reservoir and the surrounding rocks. Results obtained during geomechanical studies allow for defining crucial parameters (strength, elastic moduli) for determining the optimal orientation of the horizontal section of the drilling [22-24], design of the hydraulic fracturing process [25,26], and assessment of 
borehole stability [27-30]. All these elements contribute to a better assessment of the effectiveness of making the deposit available and allow for more economically viable exploitation of natural gas accumulated in shale complexes.

A distinctive feature of shales is a heterogeneity [27], which causes significant anisotropy. Strong mechanical anisotropy is affected by the lamination of clay minerals [31-33], the content of organic matter [34-37], and thermal maturity [38,39]. Moreover, anisotropy is caused by stress-induced preferential closure of fractures and microcracks as well as fractures created in paleo-stress environments [22,40].

Anisotropy is usually determined through a series of triaxial compression tests on rock specimens cored in different directions i.e., $0^{\circ}, 45^{\circ}, 60^{\circ}$, and $90^{\circ}$ [27]. Another useful method for determining textural anisotropy and stress-induced anisotropy is the ultrasonic investigation of shale samples [41-44]. Ultrasonic methodology was used by Hornby [45] to analyse of influence of porosity and confining pressure on quantity of anisotropy. Ultrasonic velocity anisotropy in the rock provides information of variability of the dynamic elastic moduli in modern geomechanics. For example, Moska et al. [46] calculated the Young's modulus and Poisson's ratio from wave velocities and used these dynamic elastic moduli to determine the brittleness index, which is typically used to predict rock susceptibility for hydraulic fracturing.

Sone and Zoback $[12,13]$ analysed the anisotropy from the difference in how the farfield stress is distributed (stress partitioning) to the constituent minerals, depending on the loading direction of treated shales as a mixture of soft (clay and organic matter) and stiff (quartz, feldspars, carbonates) components distributed in fine horizontal layers. Sone and Zoback [13] quantified the stress-partitioning to analyse the shale elastic anisotropy and to determine the one-dimensional creep behaviour under uniaxial loading. Trzeciak et al. [47] extended parameters, describing creeping to three dimensions in order to construct shale creep constitutive relations that are more directly applicable to geomechanical field problems. Furthermore, Rybacki et al. [48] consider that long-term creep experiments are required to estimate in situ stress anisotropy and the "healing behavior" of hydraulically induced fractures.

This paper presents the strength-strain parameters of shales from the Baltic Basin. The study was focused on determining the mechanical properties of siltstones and claystones, which are significant for gas exploitation from unconventional resources in Poland. It is the first time that the detailed mechanical properties of Baltic shales have been published for that scale. Available papers, so far, describe investigations performed on limited numbers of samples for selected formations only. Baltic shales are extremely variable, so calculating strength-strain parameters and determining anisotropy based only on two samples is not representative for all Baltic shale formations [47]. This work presents the results of 44 strength-strain tests. Each formation is represented by a few samples. Cutting out the samples with a diameter of $1.5 \mathrm{in}$, perpendicular and parallel to lamination from the same section of the drill core, is also novel. Laboratory geomechanical analyses include also the analysis of mechanical anisotropy based on an assessment of elastic parameters of the studied rocks. Understanding anisotropy and its causes is very important for the correct interpretation of seismic studies and microseismic monitoring [49-53].

\section{Materials and Methods}

Laboratory analyses were performed on siltstone-claystones (shales), whose sedimentation took place in the early Palaeozoic Baltic Basin (Figure 1). These rocks are characterised by a high content of clay minerals [54], a significant contribution of organic matter $[55,56]$, and low permeability $[57,58]$. Due to low permeability of the shales, hydraulic fracturing is performed within them [59-64]. Hydraulic fracturing causes the development of a dense network of fractures and fissures in the fractured rock layer, allowing for the exploitation of shale gas [16-19,65]. Hydraulic fracturing is the most common fracture stimulation technique. However, this procedure causes significant environmental problems, such as groundwater contamination [66], wastewater treatment [66], air pollu- 
tion [67], and clay expansion. In contrast, liquid nitrogen $\left(\mathrm{LN}_{2}\right)$ fracking is considered as one of the best alternatives compared to hydraulic fracturing due to its eco-friendly nature [68]. The contact of $\mathrm{LN}_{2}$ with rock samples sharply decreases the temperature of the rock, thereby resulting in a large number of microcracks and causing an improvement in the pore structure and connectivity. The most striking characteristic of liquid nitrogen fracturing is the supercryogenic characteristic of the fluid, which poses greater damage to the shale in comparison to other conventional fracturing technologies [69].

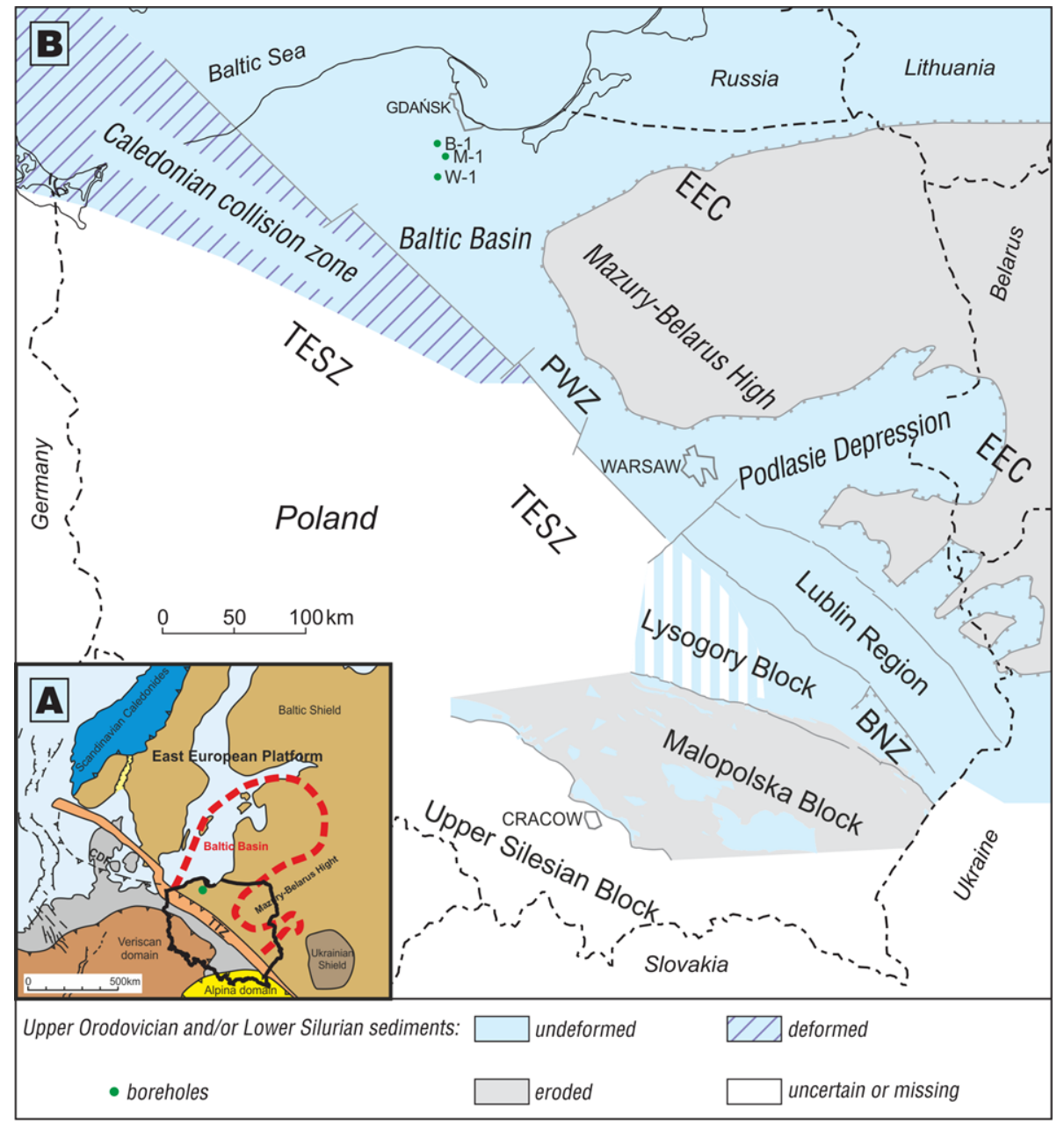

Figure 1. Location of the analysed shale gas boreholes (green dots) with regard to (A) lower Paleozoic Baltic Basin (CDF-Caledonian Deformation Front, TTZ—Teisseyre-Tornquist Zone [70]), modified, and (B) lower Paleozoic sedimentary basins and area covered by Upper Ordovician and lower Silurian shales (PWZ_Płock-Warsaw Zone, BNZ—Biłgoraj-Narol Zone, EEC—East European Craton, TESZ-Trans-European Suture Zone [71]), modified.

Drill cores, from which the samples were cut out for the analyses, came from three boreholes in northern Poland: B-1, M-1, and W-1. The samples were cut out from drill cores collected from various depths in the range of $3600-4000 \mathrm{~m}$. The samples were collected from lithostratigraphic units representing the Upper Ordovician (Sasino Claystones Formation) and lower Silurian (Pelplin Claystones Formation, Pasłęk Claystones Formation, Jantar Bituminous Claystones Member). These units span a stratigraphic interval from the Caradocian Stage to the Wenlock Series [72]. The position of the claystone formations, from which the samples were collected for the studies, is presented on the lower Palaeozoic stratigraphic log for the western slope of the East European Craton (Figure 2). 


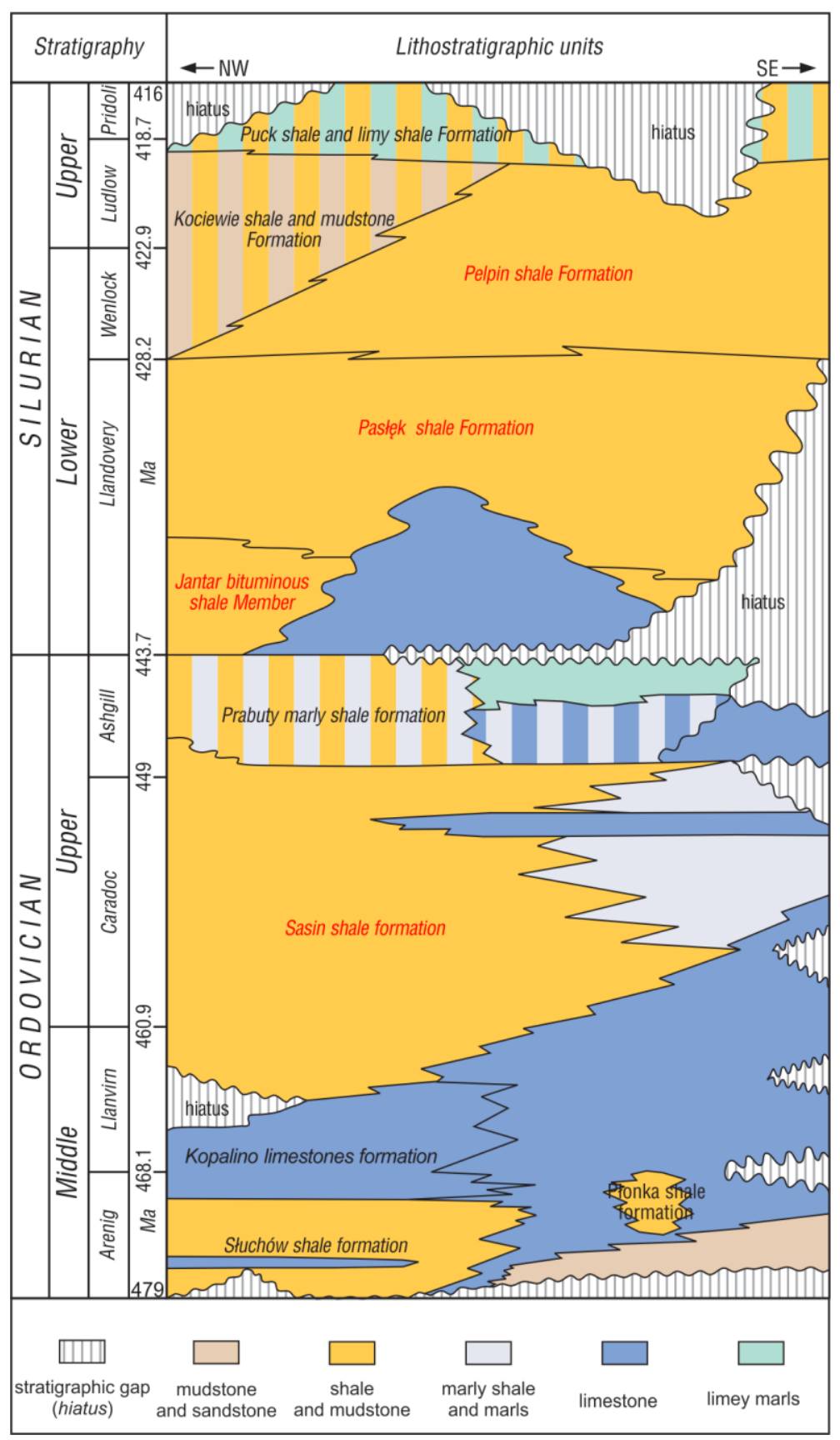

Figure 2. Position of claystone formations, from which the samples were collected for the studies (red) on the lower Palaeozoic stratigraphic log for the western slope of the East European Craton [71], modified.

\subsection{Specimen Characteristics}

The mineral composition of particular samples was determined using X-ray diffraction (XRD), based on Rietveld's [73] method, using SIROQUANT software [74]. The organic matter content was determined using Rock-Eval pyrolytic analysis [75]. The results are presented in Table 1. 
Table 1. Value ranges and average values (in parentheses) of mineral composition, TOC content, bulk density, porosity, and open porosity in particular rock formations.

\begin{tabular}{|c|c|c|c|c|c|c|}
\hline $\begin{array}{l}\text { Sample } \\
\text { Group }\end{array}$ & $\begin{array}{l}\text { QFP } \\
{[\%]}\end{array}$ & $\begin{array}{c}\text { Carbonate } \\
{[\%]}\end{array}$ & Clay [\%] & $\begin{array}{c}\text { TOC } \\
\text { [\%Weight] }\end{array}$ & $\begin{array}{c}\text { Bulk Density } \\
{\left[\mathrm{kg} / \mathrm{m}^{3}\right]}\end{array}$ & $\begin{array}{c}\text { Open Porosity } \\
{[\%]}\end{array}$ \\
\hline Pelplin & $\begin{array}{c}36.8-46.5 \\
{[42.0]}\end{array}$ & $\begin{array}{c}6.2-15.6 \\
{[11.5]}\end{array}$ & $\begin{array}{c}43.4-49.4 \\
{[46.4]}\end{array}$ & $\begin{array}{c}1.1-1.8 \\
{[1.4]}\end{array}$ & $\begin{array}{c}2450-2600 \\
{[2540]}\end{array}$ & $\begin{array}{c}1.03-4.14 \\
{[2.5]}\end{array}$ \\
\hline Pasłęk & $\begin{array}{c}31.4-37.9 \\
{[35.2]}\end{array}$ & $\begin{array}{c}4.9-8.8 \\
{[7.3]}\end{array}$ & $\begin{array}{c}53.5-61.5 \\
{[57.5]}\end{array}$ & $\begin{array}{c}0.1-1.7 \\
{[1.0]}\end{array}$ & $\begin{array}{c}2530-2620 \\
{[2560]}\end{array}$ & $\begin{array}{c}1.78-5.36 \\
{[3.2]}\end{array}$ \\
\hline Jantar 1 & $\begin{array}{c}27.2-45.9 \\
{[34.5]}\end{array}$ & $\begin{array}{c}20.7-34.4 \\
{[26.5]}\end{array}$ & $\begin{array}{c}32.8-49.5 \\
{[38.8]}\end{array}$ & $\begin{array}{c}2.6-3.9 \\
{[3.3]}\end{array}$ & $\begin{array}{c}2340-2490 \\
{[2410]}\end{array}$ & $\begin{array}{c}1.43-6.93 \\
{[3.5]}\end{array}$ \\
\hline Jantar 2 & $\begin{array}{c}37.7-43.5 \\
{[41.0]}\end{array}$ & $\begin{array}{c}2.3-10.5 \\
{[4.1]}\end{array}$ & $\begin{array}{c}48.8-59.3 \\
{[54.9]}\end{array}$ & $\begin{array}{c}1.8-6.1 \\
{[3.8]}\end{array}$ & $\begin{array}{c}2280-2640 \\
{[2420]}\end{array}$ & $\begin{array}{c}2.52-8.12 \\
{[4.2]}\end{array}$ \\
\hline Sasino 1 & $\begin{array}{c}51.4-58.0 \\
{[54.3]}\end{array}$ & $\begin{array}{c}0.9-3.2 \\
{[2.5]}\end{array}$ & $\begin{array}{c}38.8-46.3 \\
{[43.2]}\end{array}$ & $\begin{array}{c}2.5-6.9 \\
{[4.7]}\end{array}$ & $\begin{array}{c}2250-2530 \\
{[2380]}\end{array}$ & $\begin{array}{c}2.33-4.82 \\
{[3.7]}\end{array}$ \\
\hline Sasino 2 & $\begin{array}{c}37.4-43.5 \\
{[40.4]}\end{array}$ & $\begin{array}{c}1.4-4.4 \\
{[2.6]}\end{array}$ & $\begin{array}{c}53.9-58.3 \\
{[57.0]}\end{array}$ & $\begin{array}{c}2.7-4.3 \\
{[3.3]}\end{array}$ & $\begin{array}{c}2290-2510 \\
{[2410]}\end{array}$ & $\begin{array}{c}3.38-8.12 \\
{[8.4]}\end{array}$ \\
\hline
\end{tabular}

Samples from the Pelplin Formation are characterised by a similar mineral composition (Figure 3). They contain about $46.4 \%$ clay minerals, $42.0 \%$ quartz, feldspars and pyrite (QFP), and $11.5 \%$ carbonates, and the average content of organic matter (TOC) is about $1.4 \mathrm{wt} . \%$. Samples from the Pasłęk Formation are characterised by an elevated content of clay minerals (57.5\%), a lower content of QFP minerals (35\%), and a low carbonate content $(7.3 \%)$. The average TOC content in this formation does not exceed $1 \mathrm{wt} . \%$. Samples from the Jantar Member and Sasino Formation were subdivided into two groups based on the mineral composition. Samples from subgroup 2 have a higher contribution of clay minerals compared to samples from subgroup 1. Samples from Jantar Member 1 have a high content of carbonates (average of 26.5\%) compared to samples from Jantar Member 2, which contain much lower levels of carbonates (average of $4.1 \%$ ). Samples from Sasino Formation may be distinguished by the QFP (quartz, feldspar, pyrite) minerals. Samples from Sasino Formation 1 contain more QFP minerals (average of 54.3\%) than samples from Sasino Formation 2 (average of $40.4 \%$ ).

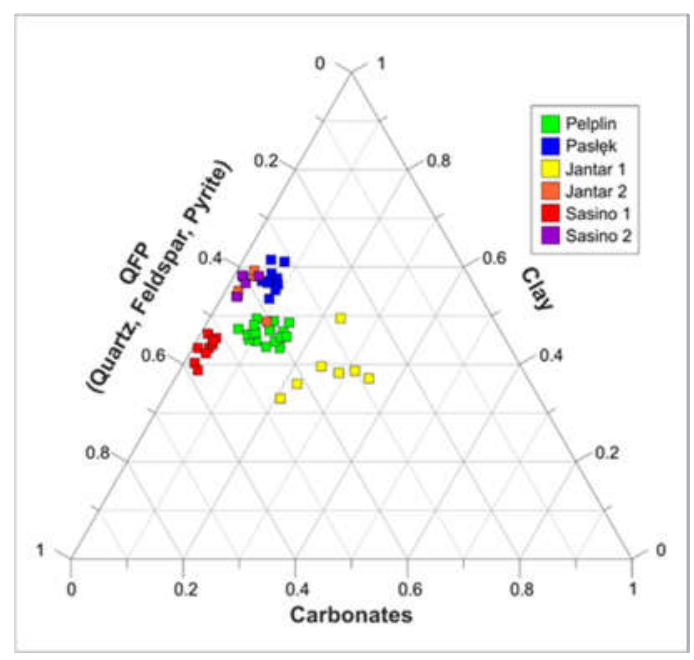

Figure 3. Mineral composition of all samples studies.

\subsection{Sample Preparation}

Triaxial tests required preparation of cylinder samples, 1.5 inch in diameter and $\sim 3$ inches high. A vertical sample and a horizontal sample were cut out from each section of the drill core in a direction perpendicular and parallel to shale lamination, respectively (Figure 4). Horizontal and vertical samples were cut out from the same sections of drill 
cores in order to determine mechanical anisotropy. Polishing and grinding of the cylinder ends ensured that the two surfaces were parallel to one other, according to the ASTM (D 4543-01) standard [76].
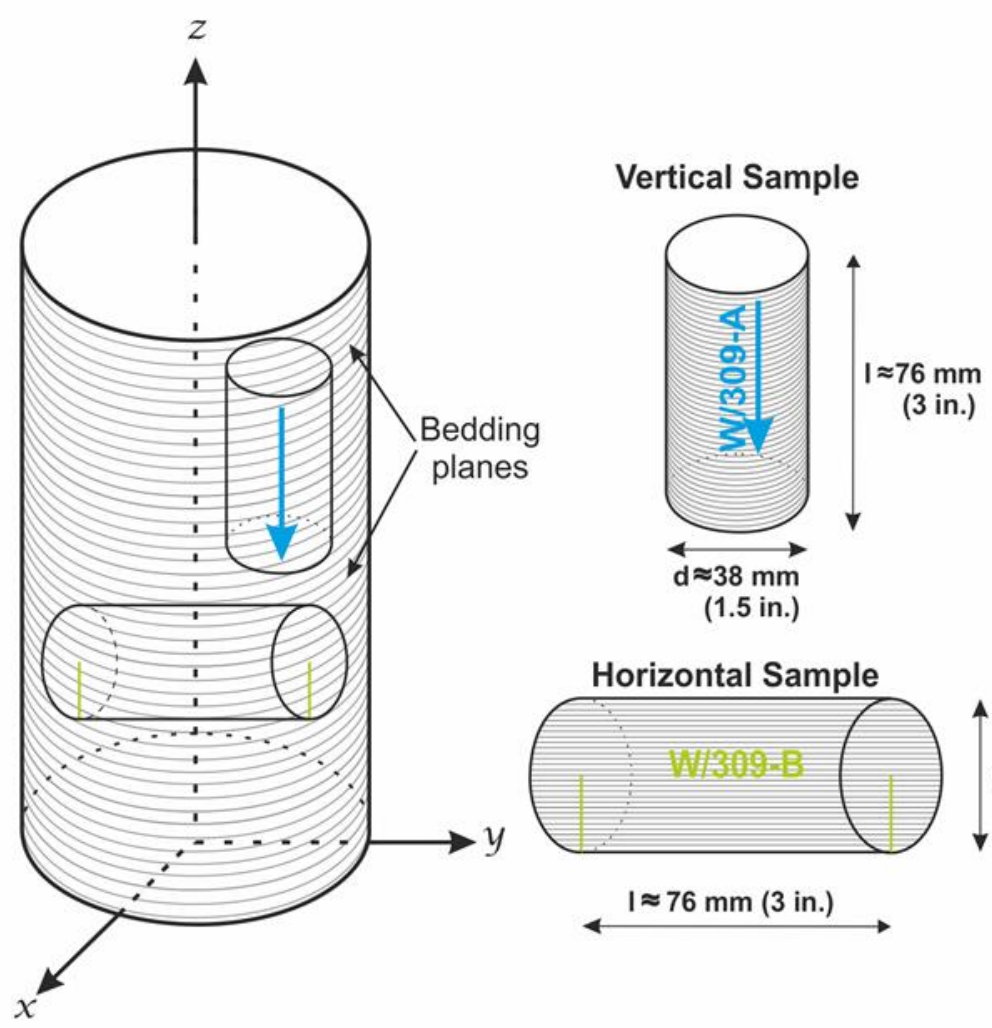

Horizontal Sample

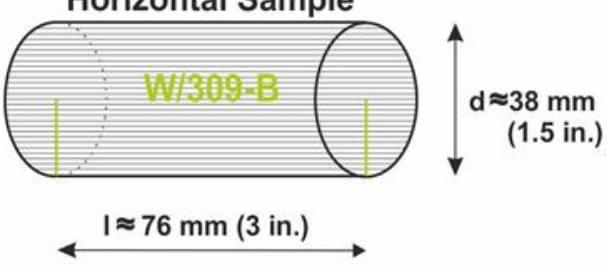

Figure 4. Scheme of cutting out samples perpendicular and parallel to lamination from one drill core section.

\subsection{Experimental Equipment}

Triaxial tests were performed with the application of a servo-hydraulic Material Test System (MTS 815). The increase in temperature in the triaxial cell was obtained by three electrical heaters, $2000 \mathrm{~W}$ each. The temperature in the cell was monitored by a thermocouple installed in its centre. Confining pressure in the triaxial cell was achieved using compressed oil. The application of a liquid medium required the surface of the samples to be protected against oil immersion into pore space and microfractures; therefore, prior to the analysis, each sample was protected with a heat-shrink jacket against surrounding liquids. Two axial transducers measured axial strain, and a chain type transducer measured lateral strain (Figure 5). Volumetric strain (1) was determined using the following formula:

$$
\varepsilon_{\mathrm{v}}=\varepsilon_{\mathrm{z}}+2 \varepsilon_{\mathrm{x}, \mathrm{y}}
$$

where

$\varepsilon_{\mathrm{V}}$-volumetric strain,

$\varepsilon_{\mathrm{z}}$-axial strain,

$\varepsilon_{x, y}$-lateral strain. 


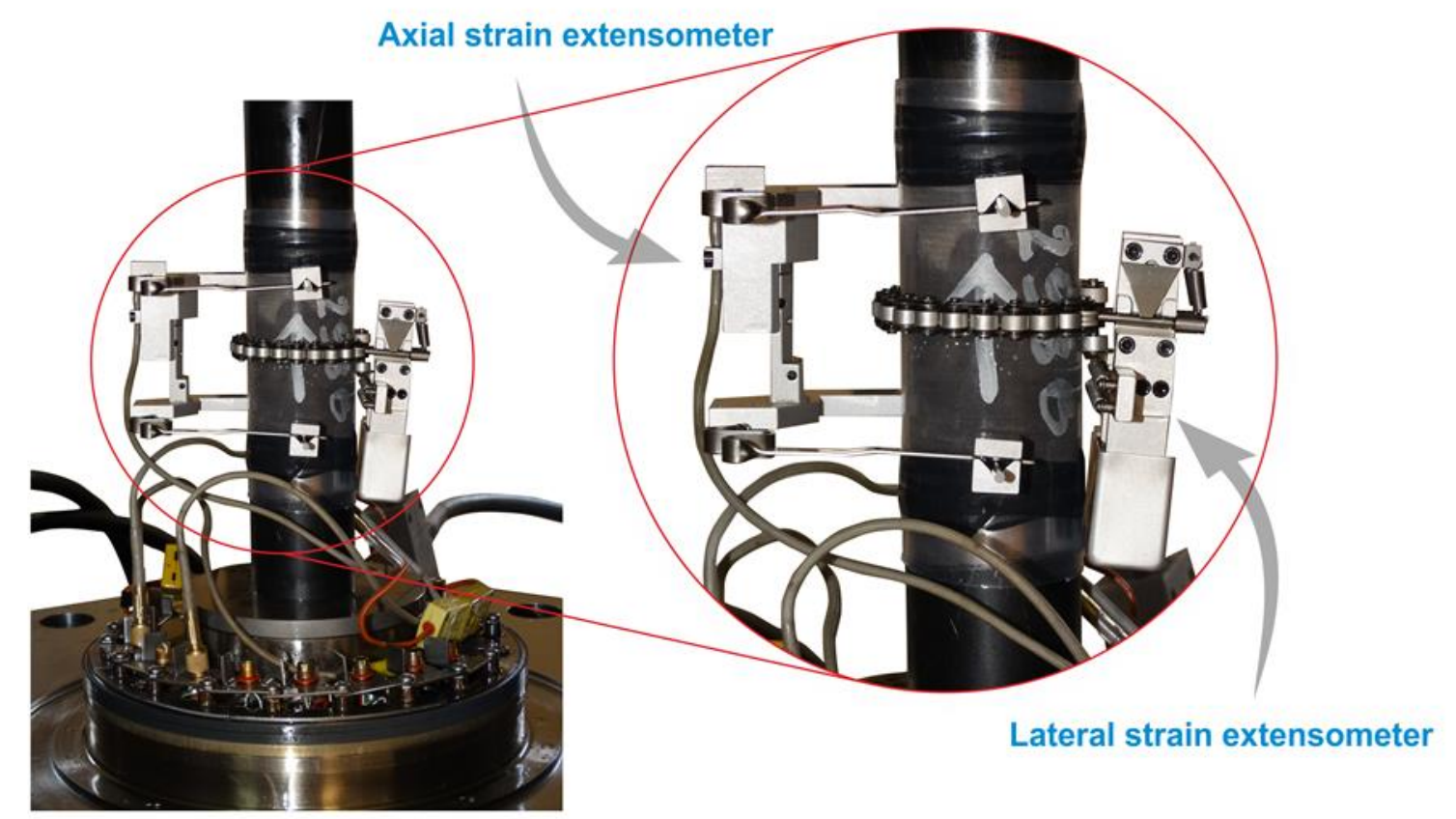

Figure 5. Sample prepared for analysis with extensometers attached.

Prior to analysis, the samples were kept at room temperature. Saturation was considered low enough for the poroelastic effects to be considered negligible. The samples were not subject to additional saturation prior to the analyses.

\subsection{Experimental Procedure}

Triaxial analyses were performed as single failure tests (Figure 6), according to the suggestions of ISRM [77] and guidelines of American standards (ASTM) [78] and European standards (Eurocode) [79]. The tests were conducted at a constant temperature of $\mathrm{T}=85^{\circ} \mathrm{C}$ and stable confining pressure $\mathrm{p}_{\mathrm{c}}=50 \mathrm{MPa}$ in order to reflect the temperature and effective stresses under in situ conditions. Confining pressure was applied on the rock sample at a rate of $10 \mathrm{MPa} / \mathrm{min}$. Temperature and confining pressure were achieved in the cell prior to axial compression and maintained at a stable level during the whole test.

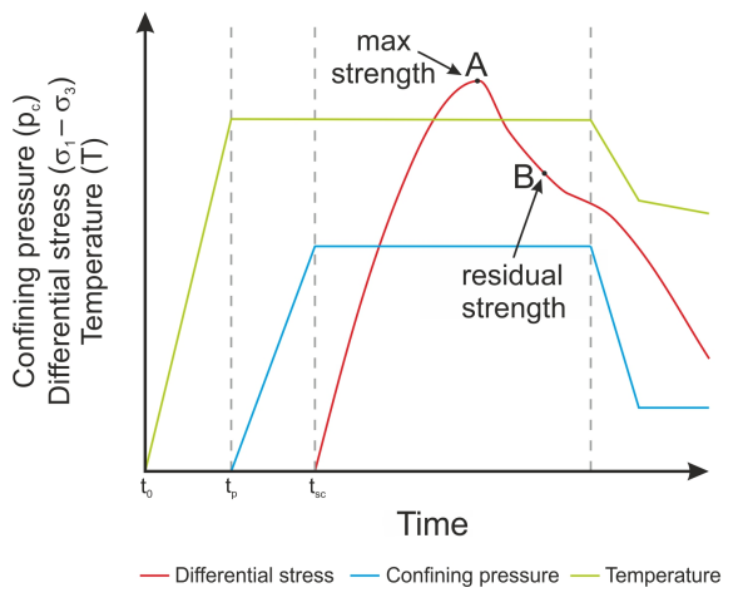

Figure 6. Ideogram of single failure tests: green and blue curve-temperature $(T)$ and pressure $\left(\mathrm{p}_{\mathrm{c}}\right)$, respectively, increase to the expected study level; red curve-compression under stable temperature $(\mathrm{T})$ and pressure $\left(\mathrm{p}_{\mathrm{c}}\right)$ conditions. 
Triaxial tests were performed at a constant strain rate of $10-5 \mathrm{~s}^{-1}$, up to complete destruction of the sample along the shear surface. Due to direct measurements, it was possible to obtain the following deformation curves: differential stress $\left(\sigma_{1}-\sigma_{3}\right)$-axial strain $\left(\varepsilon_{\mathrm{z}}\right)$, lateral strain $\left(\varepsilon_{\mathrm{x}, \mathrm{y}}\right)$ and volumetric strain $\left(\varepsilon_{\mathrm{v}}\right)$. Based on these, static elastic parameters were determined, including Young's modulus (E) and Poisson's ratio $(v)$.

\section{Results and Discussion}

\subsection{Estimation of Strength and Static Moduli}

All strength analyses were performed under the same temperature $(\mathrm{T})$ and pressure $\left(p_{c}\right)$ conditions. Therefore, the parameter dataset obtained from the performed analyses in a triaxial cell did not depend on temperature and confining pressure. Consequently, parameter values depended on factors related to the lithology of the rock formations, structural features of single samples, and orientation of rock samples with regard to lamination.

Young's modulus and Poisson's ratio are elastic parameters. These parameters were determined using an individual interpretation procedure based on the phenomenological description of rock deformation under loading [80] and were also based on guidelines of American standards (ASTM) [81] and the recommendations of ISRM [77]. In this case, deformation curves obtained from strength analyses were applied for estimating these parameters (Figure 7). Average Young's modulus $\left(\mathrm{E}_{\mathrm{av}}\right)$ was determined on a straight section of the differential strain $\left(\sigma_{1}-\sigma_{3}\right)$-axial strain $\left(\varepsilon_{\mathrm{z}}\right)$ curve. Average Poisson's ratio $\left(v_{\mathrm{av}}\right)$ was defined as the ratio (quotient) between the value of axial strain $\left(\varepsilon_{\mathrm{z}}\right)$ and lateral strain $\left(\varepsilon_{x, y}\right)$ for a straight section of all three stresses-axial, lateral and volumetric strain characteristics. The ideogram of determining maximal differential stress, Young's modulus, and Poisson's ratio is presented in Figure 7. The results obtained from strength analyses in a triaxial stress state are presented in Table 2.

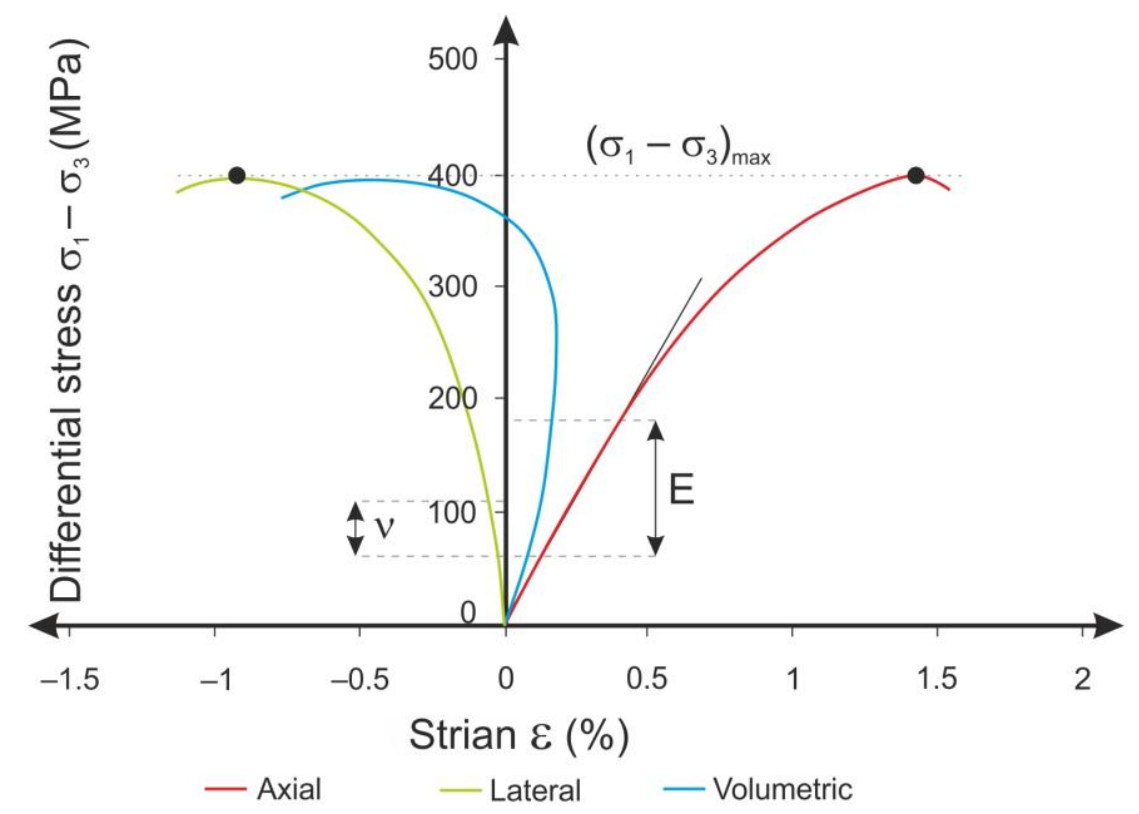

Figure 7. The scheme of determining the analyzing parameters from single failure tests. 
Table 2. Value ranges of maximal value of differential stress $\left(\sigma_{1}-\sigma_{3}\right)_{\max }$, average Young's modulus ( $\left.\mathrm{E}_{\mathrm{av}}\right)$, and average Poisson's ratio $\left(v_{\mathrm{av}}\right)$ in particular rock formations.

\begin{tabular}{|c|c|c|c|c|}
\hline \multirow[t]{2}{*}{ Sample Group } & \multirow[t]{2}{*}{ Orientation } & $\begin{array}{c}\text { Maximal } \\
\text { Differential Stress } \\
\left(\sigma_{1}-\sigma_{3}\right)_{\max }\end{array}$ & $\begin{array}{l}\text { Young's Static } \\
\text { Modulus } \\
\left(E_{a v}\right)\end{array}$ & $\begin{array}{c}\text { Poisson's Static Ratio } \\
\left(v_{\mathrm{av}}\right)\end{array}$ \\
\hline & & [MPa] & [GPa] & {$[-]$} \\
\hline \multirow{2}{*}{ Pelplin } & Vertical & $188-223$ & $18.5-27.3$ & $0.14-0.23$ \\
\hline & Horizontal & $213-258$ & $38.4-47.8$ & $0.18-0.30$ \\
\hline \multirow{2}{*}{ Pasłęk } & Vertical & 173-206 & $20.5-30.2$ & $0.18-0.28$ \\
\hline & Horizontal & 174-219 & $41.9-48.7$ & $0.23-0.28$ \\
\hline \multirow{2}{*}{ Jantar 1} & Vertical & $191-241$ & $22.6-24.9$ & $0.23-0.24$ \\
\hline & Horizontal & $206-263$ & $39.7-50.4$ & $0.30-0.32$ \\
\hline \multirow{2}{*}{ Jantar 2} & Vertical & $104-123$ & $15.3-16.2$ & $0.19-0.23$ \\
\hline & Horizontal & $123-176$ & $33.7-47.5$ & $0.22-0.30$ \\
\hline \multirow{2}{*}{ Sasino 1} & Vertical & 178-194 & $18.6-22.1$ & $0.19-0.25$ \\
\hline & Horizontal & $220-240$ & $34.5-57.2$ & $0.22-0.32$ \\
\hline \multirow{2}{*}{ Sasino 2} & Vertical & 180 & $16.1-20.0$ & $0.16-0.17$ \\
\hline & Horizontal & 179 & $37.4-45.1$ & $0.22-0.26$ \\
\hline
\end{tabular}

Examples of deformation curves for samples cut out parallel and perpendicular to lamination from the same drill core section are presented in Figure 8.

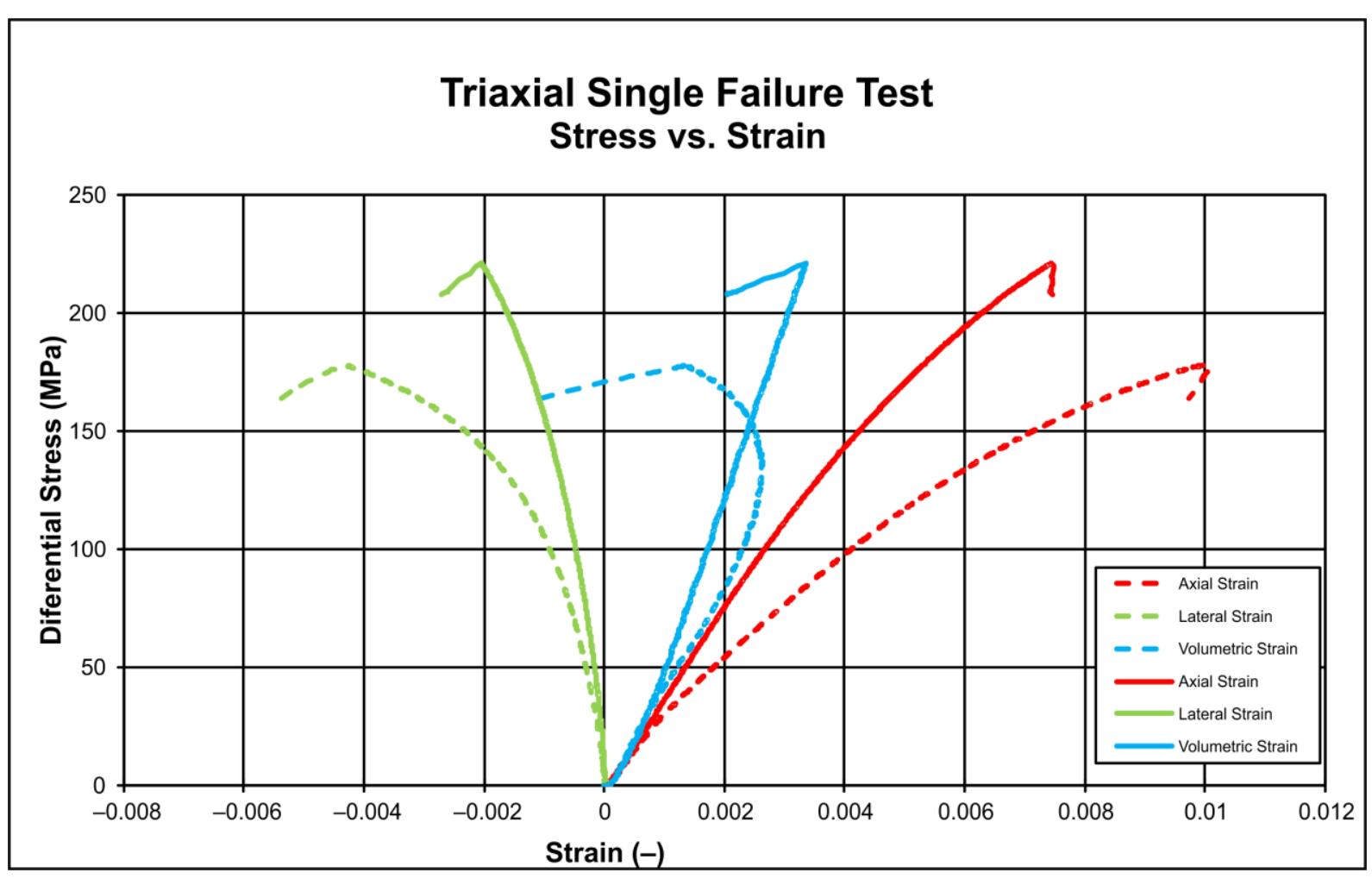

Figure 8. Examples of deformation curves obtained on the basis of strain and stress measurements for horizontal (solid lines) and vertical (dashed lines) samples.

Comparison of the obtained sets of deformation curves (Figure 8) for samples cut out parallel and perpendicular to lamination shows a strong strength anisotropy of the siltstone-claystone rocks. This is reflected in the larger values of maximal differential stress 
and a more vertical (steep) curve of differential stress of axial strain for the samples cut out parallel to lamination compared to the samples cut out perpendicular to lamination.

The Ordovician and Silurian rocks studied are characterised by strength anisotropy (Figure 9). This is confirmed by the results of maximal differential stress. Horizontal samples from all formations reached higher strength values than vertical samples (Table 2). Disintegration of the structure of vertical samples took place due to application of smaller loading in comparison to horizontal samples. Horizontal samples were destroyed after application of a much larger strength. Strength anisotropy for vertical and horizontal samples cut out from the same drill core section is well reflected on deformation curves obtained on the basis of measurements of strain and deformation as presented in Figure 8. These curves show that destruction of a horizontal sample requires application of much larger strength; therefore, this sample attained a higher value of maximal differential stress than the vertical sample, which was destroyed at a stress $20 \%$ lower than applied on the horizontal sample.

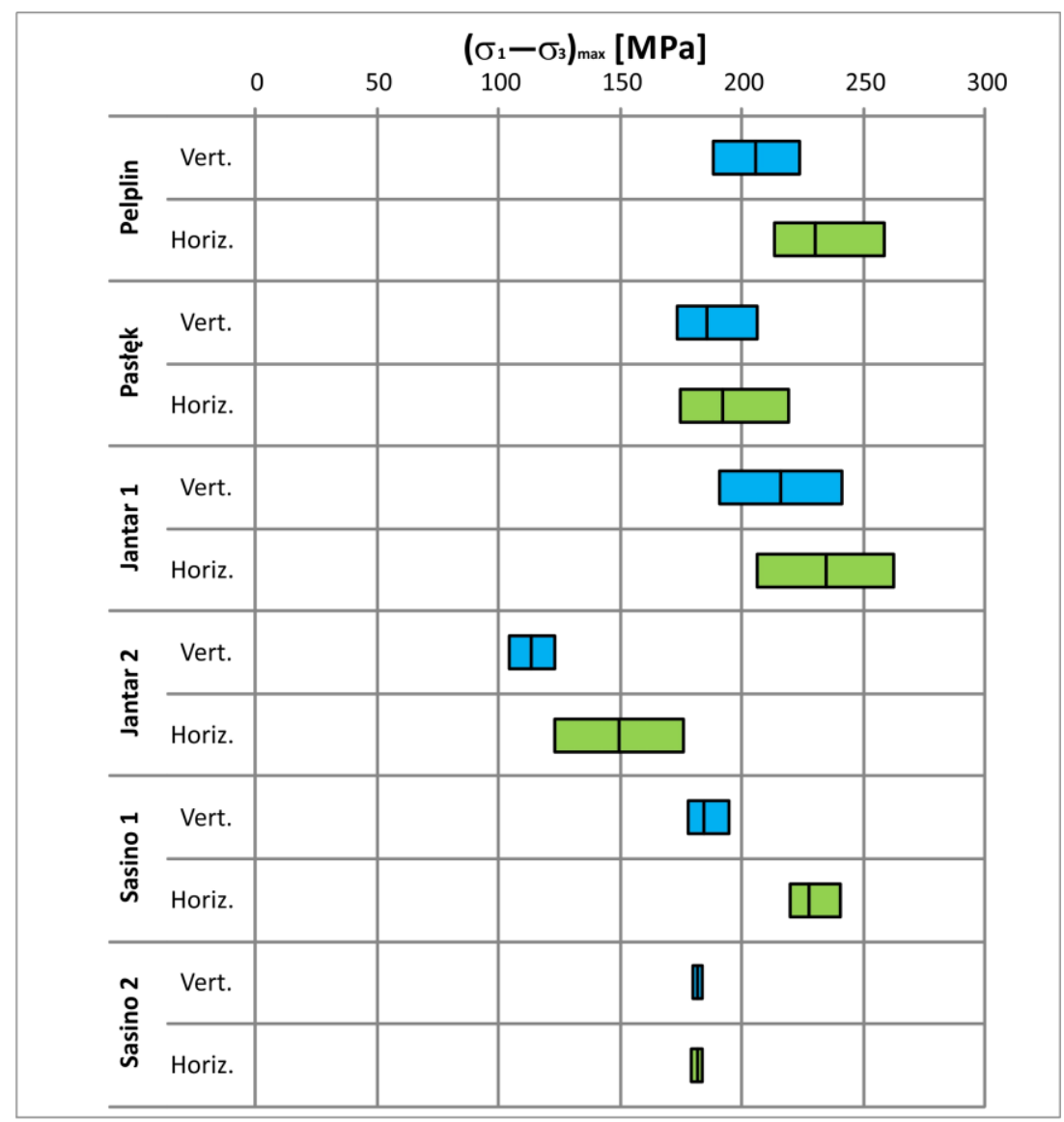

Figure 9. Variability ranges (minimum, average, maximum) of the value of maximal differential strain $\left(\sigma_{1}-\sigma_{3}\right)_{\max }$ in particular rock units.

In current research, the values of Young's modulus were practically twice as high for horizontal samples as for vertical samples. Horizontal samples, parallel to lamination, obtained values of Young's modulus in the range of $33 \mathrm{GPa}$ to $57 \mathrm{GPa}$, whereas vertical samples, perpendicular to lamination, had values in the range of $15 \mathrm{GPa}$ to $30 \mathrm{GPa}$ (Figure 10). According to Trzeciak et al. [47], the horizontal Young's modulus of the shale layers (Pasłęk, Jantar, and Sasino formations) ranges from $37 \mathrm{GPa}$ to $60 \mathrm{GPa}$, while the range for the vertical Young's modulus ranges from $21 \mathrm{GPa}$ to $27 \mathrm{GPa}$. 


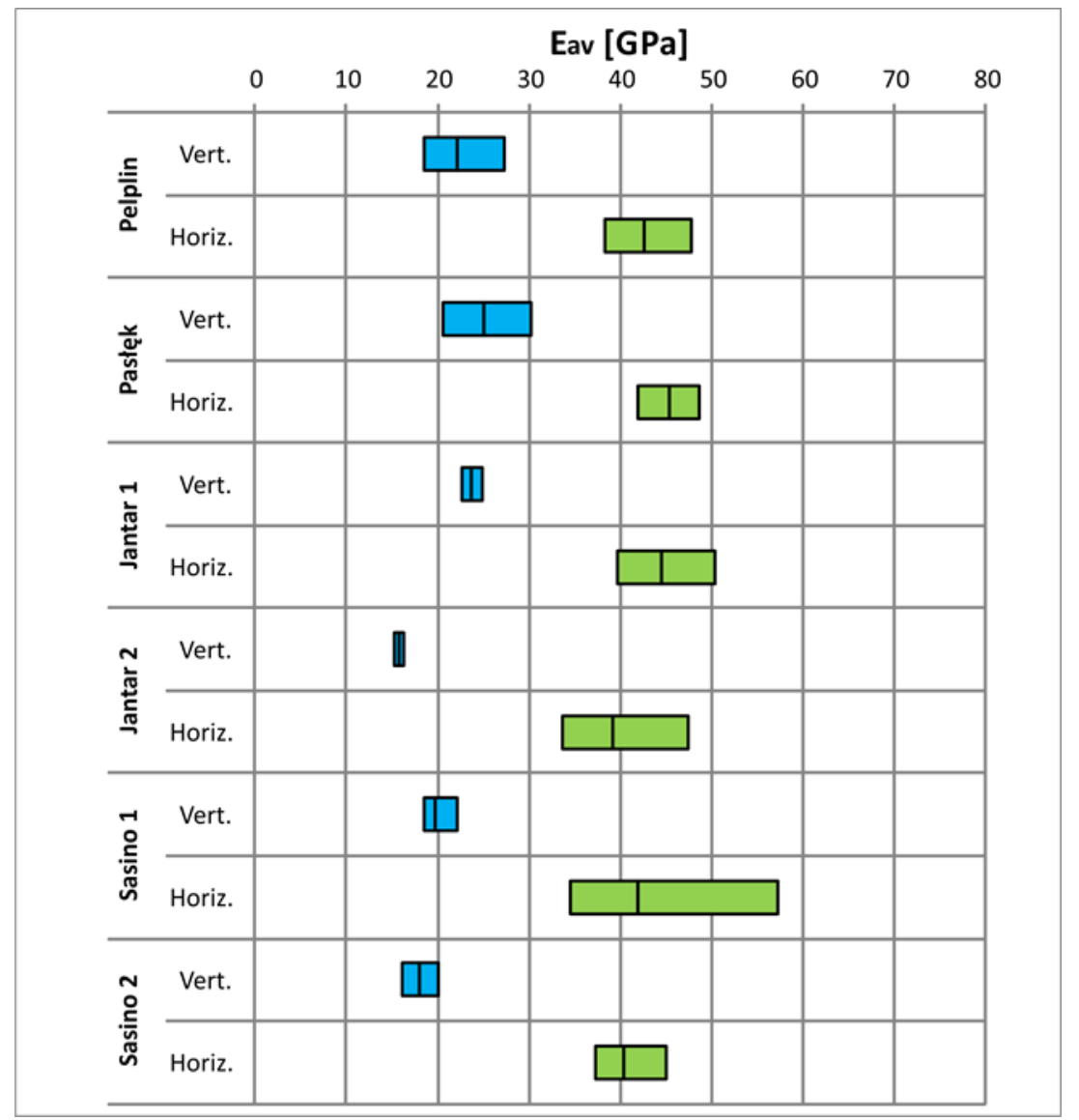

Figure 10. Variability ranges (minimum, average, maximum) of Young's modulus $\left(\mathrm{E}_{\mathrm{av}}\right)$ in particular rock units.

The sizable difference in the values of Young's modulus depending on the measurement direction is caused by the much lower susceptibility of horizontal samples to axial strain than the vertical samples. Axial strains registered during compression of vertical samples were much larger, thus influencing the lower values of the elastic modulus.

Comparison of the obtained results of Young's modulus (Table 2) with the mineral composition of particular rock units (Table 1) shows that samples with a higher content of carbonates and QFP minerals attained higher values of Young's modulus than samples dominated by clay minerals and organic matter (e.g., Jantar 1 vs. Jantar 2 and Sasino 1 vs. Sasino 2). These results confirm the studies of Dohnalik et al. [82], performed on the same rock formations from different boreholes in the Baltic Basin. These studies have shown that the values of Young's modulus and Poisson's ratio strongly depend on the mineral composition of the rocks. Values of Young's modulus are higher for samples with a higher content of carbonates, and Poisson's ratio correlates well with the clay mineral content in the rock sample.

The presented studies also show a anisotropy in the values of Poisson's ratio depending on the sample orientation (Figure 11). Vertical samples are characterised by much lower values of Poisson's ratio than the horizontal samples. Poisson's ratio for vertical values is from 0.14 to 0.28 , and for horizontal samples, it is from 0.18 to 0.32 . There was no positive correlation between Poisson's ratio and the content of clay minerals in the sample. Higher values of Poisson's ratio for horizontal samples are the result of smaller axial strain in horizontal samples during their compression in a triaxial cell. 


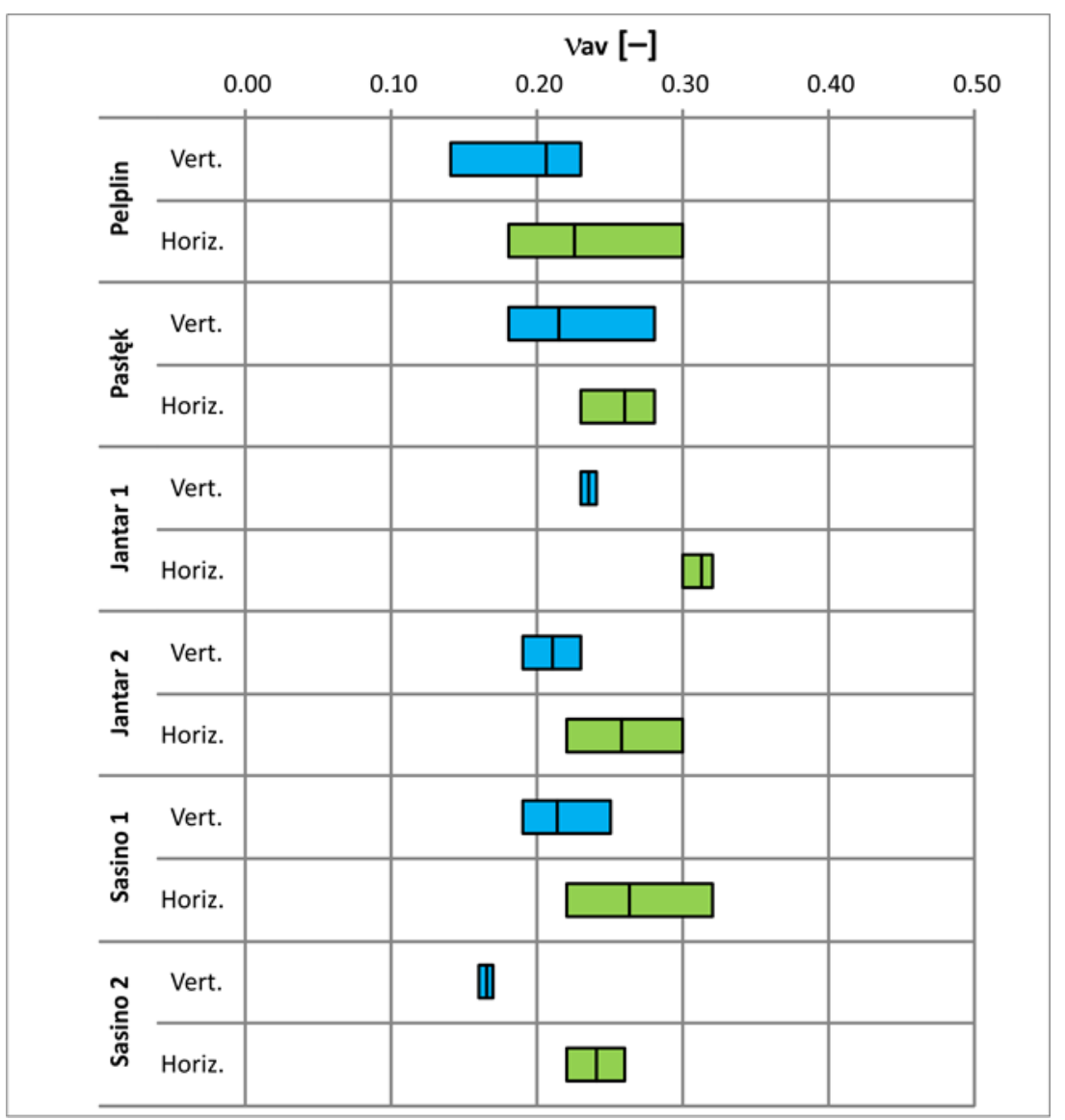

Figure 11. Ranges (minimum, average, maximum) of Poisson's ratio $\left(v_{\mathrm{a} v}\right)$ in particular rock units.

The obtained data show that horizontal samples (parallel to lamination) are stiffer than vertical samples (perpendicular to lamination) and that samples with a higher content of stiffer minerals (QFP and carbonates) reach higher values of Young's modulus compared to more plastic samples with a higher content of clay minerals. Based on the analysis of triaxial tests, it was established that the elastic parameters of shales depend on the orientation of the mineral and organic components in the rock. Horizontal samples are less susceptible to axial strain compared to vertical samples; therefore, shales are characterised by large elastic anisotropy.

\subsection{Anisotropy}

The occurrence of mechanical anisotropy in shale formations was also tested based on three anisotropy ratios, determined on the basis of values of $\left(\sigma_{1}-\sigma_{3}\right)_{\max }, \mathrm{E}_{\mathrm{av}}$, and $v_{\mathrm{av}}$ obtained for samples cut out parallel and perpendicular to lamination from the same drill core section. It should be emphasized that values of the anisotropy ratio above one indicate to the presence of anisotropy.

According to Niandou et al. [83], the degree of strength anisotropy for transversely isotropic rocks is determined by the ratio of failure strength in parallel and perpendicular bedding orientation $\mathrm{A}\left(\sigma_{1}-\sigma_{3}\right)_{\max }$ (Equation (2)). Additionally the quantitative assessment of anisotropy of the rocks studied was performed based on anisotropy ratios: Young's modulus ( $\left.\mathrm{A}_{\text {Eav }}\right)$ (Equation (3)) and Poisson's ratio (deformation) $\left(\mathrm{A}_{\text {vav }}\right)$ (Equation (4)). They were determined based on the values of particular parameters, according to the following formulas:

$$
A_{\left(\sigma_{1}-\sigma_{3}\right)_{\max }}=\frac{\left(\sigma_{1}-\sigma_{3}\right)_{\max _{\mathrm{II}}}}{\left(\sigma_{1}-\sigma_{3}\right)_{\max \perp}}
$$




$$
\begin{aligned}
& A_{E a v}=\frac{E_{a v I I}}{E_{a v \perp}} \\
& A_{v a v}=\frac{v_{a v I I}}{v_{a v \perp}}
\end{aligned}
$$

The assessment of strength anisotropy in the analysed rocks was conducted based on the anisotropy ratio of the maximal differential stress. For most clay units (except Sasino 2), the obtained values of the strain anisotropy ratio only slightly exceeded one (Table 3). For each drill core section from the studied units, samples cut out parallel to lamination had a higher strength than samples cut out perpendicular to lamination, which points to the presence of strength anisotropy. Distinct strength anisotropy was not observed only for Sasino Formation 2. In this case, only one anisotropy ratio was observed, equal to one, for two samples cut out vertically and horizontally from one drill core section.

Table 3. Values of anisotropy ratios of maximal differential strain $\left(\mathrm{A}_{(}\left(\sigma_{1}-\sigma_{3}\right) \max \right)$, Young's modulus $\left(\mathrm{A}_{\text {Eav }}\right)$, and Poisson's ratio $\left(\mathrm{A}_{\text {vav }}\right)$ in particular rock formations.

\begin{tabular}{ccccccc}
\hline Formation & Pelplin & Pasłęk & Jantar 1 & Jantar 2 & Sasino 1 & Sasino 2 \\
\hline $\mathrm{A}_{(} \sigma_{1}-\sigma_{3) \max }$ & $1.10-1.47$ & $1.05-1.19$ & $1.08-1.09$ & $1.12-1.55$ & $1.17-1.34$ & 1.00 \\
$\mathrm{~A}_{\text {Eav }}$ & $1.60-2.22$ & $1.76-2.11$ & $1.75-2.02$ & $2.20-2.31$ & $1.68-3.06$ & $1.86-2.41$ \\
$\mathrm{~A}_{\text {vav }}$ & $0.78-1.64$ & $1.30-1.40$ & $1.30-1.33$ & $0.96-1.42$ & $0.96-1.68$ & $1.29-1.63$ \\
\hline
\end{tabular}

The obtained values of the anisotropy ratio of Young's modulus ( $\mathrm{A}_{\text {Eav }}$ ) (Table 3) confirm the presence of strong anisotropy of Young's modulus in all shale formations. The lowest values of the anisotropy ratio of Young's modulus, in the range of 1.60, were obtained for the Pelplin Formation. This shows that the value of Young's modulus for a sample cut out parallel to lamination is $60 \%$ larger than the value obtained for a sample cut out from the same part of the drill core but perpendicular to lamination. In turn, the largest value of the anisotropy ratio of Young's modulus, in the range of 3.06, was obtained for Sasino Formation 1, for which, in the case of a horizontal sample (cut out parallel to lamination), the value of Young's modulus was over three times larger than the value for a vertical sample (cut out perpendicular to lamination).

Generally, similar trends were observed when analysing the strain anisotropy ratio (Poisson's ratio- $\mathrm{A}_{\text {vav }}$ ) (Table 3), but in this case, the differences were observed in both measurement directions, and thus the values of anisotropy ratio $\mathrm{A}_{\text {vav }}$ were much lower. The highest values of the strain anisotropy ratio, above 1.6, noted in the Pelplin, Sasino 1, and Sasino 2 formations, were twice as small as the maximal values of the anisotropy ratio of Young's modulus. The value ranges of the strain anisotropy ratio $\left(\mathrm{A}_{\text {vav }}\right)$ exceeding one indicate the presence of distinct anisotropy of Poisson's ratio in claystones from the Pasłęk and Sasino 2 formations and in Jantar Member 1. In the remaining units (Pelplin, Jantar 2, and Sasino 1$)$, despite the fact that the value of the strain anisotropy ratio $\left(\mathrm{A}_{\text {vav }}\right)$ attained values below one for samples cut out from the same section of the drill core, the average value of this ratio, above one, also indicates the presence of distinct anisotropy in these rocks.

\section{Conclusions}

The growing demand for hydrocarbons has caused significant intensification of geomechanical studies. These investigations are focused on determining the strength and strain parameters of the rocks building the reservoirs of unconventional gas and oil deposits. The results of geomechanical studies are used mainly for design of the most optimal process of hydraulic fracturing, indispensable for economically viable exploitation of gas from deposits characterised by very low permeability. The results of the mechanical properties obtained herein should enhance gas production from shale gas deposits in Poland. The presented analysis of mechanical anisotropy may be of crucial significance for successful exploitation of gas from unconventional resources. 
Triaxial tests were performed on cylindrical samples cut out perpendicular and parallel to lamination characteristic of the shales studied. Based on the performed analyses, it may be assumed that the shales are characterised by strong mechanical anisotropy. The analysed claystone units are characterised by strength anisotropy. This is confirmed by the obtained values of maximal differential stress required for destruction of the sample. Horizontal samples from all units had a higher strength than vertical samples. These conclusions can also be confirmed by anisotropy ratios determined on the basis of the values $\left(\left(\sigma_{1}-\sigma_{3}\right)_{\max }\right.$, $E_{\mathrm{av}}$, and $v_{\mathrm{av}}$ ) obtained for samples cut out parallel and perpendicular to lamination from the same drill core sections. These ratios also confirm the presence of anisotropy in most rock units studied.

The performed strength and strain tests allowed for the determination of the elastic and strain properties of the studied shales. Horizontal samples (cut out parallel to lamination) attained much higher values of Young's modulus, in the range of $33 \mathrm{GPa}$ to $57 \mathrm{GPa}$, than vertical samples (cut out perpendicular to lamination), characterised by values of Young's modulus in the range of $15 \mathrm{GPa}$ to $30 \mathrm{GPa}$. Elastic properties in the analysed shale units depended on the direction of measurement, which is reflected in the obtained values of Young's modulus. A privileged direction is observed, in which the highest values of Young's modulus were noted. This direction is parallel to lamination, where smaller axial strain was registered compared to the direction perpendicular to lamination. The Pelplin, Pasłęk, Jantar 1, Jantar 2, Sasino 1, and Sasino 2 claystone units are thus characterised by a strong elastic anisotropy (Young's modulus).

Based on single failure triaxial tests, Poisson's ratio $\left(v_{\mathrm{av}}\right)$ was determined for the analysed rock units. For horizontal samples, the range of Poisson's ratio $\left(v_{\mathrm{av}}\right)$ is from 0.18 to 0.32 , and for vertical samples, the average Poisson's ratio $\left(v_{\mathrm{av}}\right)$ is in the range of 0.13 to 0.28. Analysis of the value of Poisson's ratio for particular lithostratigraphic units shows that in most cases it was much higher for horizontal samples than for vertical samples.

The structure of clay rocks results from sedimentation and later diagenesis of sheets of clay minerals. The arrangement of clay minerals horizontally in the shale rock led to the development of internal VTI anisotropy of the rock matrix. This anisotropy causes a privileged direction in all clay units, along which the highest values of the analysed parameters were observed. This direction is parallel to lamination, in which much smaller axial strains were observed compared to the direction perpendicular to lamination. Lower Palaeozoic claystone units are thus characterised by strong anisotropy of geomechanical properties.

Laboratory results indicate that mechanical properties of gas shales are variable. It was also established that mineral composition has influence on the strength and strain properties.

Author Contributions: Conceptualization, P.M.W., A.D. and P.L.; methodology, P.M.W. A.D. and P.L.; formal analysis, P.M.W., A.D. and P.L.; investigation, P.M.W. and P.L., data curation, P.M.W.; writing-original draft preparation, P.M.W.; writing-review and editing, P.M.W., A.D. and P.L.; visualization, P.M.W.; project administration, A.D. All authors have read and agreed to the published version of the manuscript.

Funding: The research was conducted under the framework of the ShaleMech project led by Polish Oil and Gas Company (PGNiG S.A.), under the auspices of the Blue Gas Program launched by the Polish National Committee for Research and Development (NCBiR), Poland, grant no. BG2-SHALE MECH-14. Samples were provided by Polish Oil and Gas Company (PGNiG S.A.).

Institutional Review Board Statement: Not applicable.

Informed Consent Statement: Not applicable.

Data Availability Statement: Data is classified. The data is stored by the Polish Oil and Gas Company (PGNiG S.A.).

Conflicts of Interest: The authors declare no conflict of interest. 


\section{References}

1. Soeder, D.J. The successful development of gas and oil resources from shales in North America. J. Pet. Sci. Eng. 2018, 163, 399-420. [CrossRef]

2. Slatt, R. Important geological properties of unconventional resource shales. Cent. Eur. J. Geosci. 2011, 3, 435-448. [CrossRef]

3. Du, J.; Hu, L.; Meegoda, J.N.; Zhang, G. Shale softening: Observations, phenomenological behavior, and mechanisms. Appl. Clay Sci. 2018, 161, 290-300. [CrossRef]

4. Zoback, M.D.; Barton, C.A.; Brudy, M.; Castillo, D.A.; Finkbeiner, T.; Grollimund, B.R.; Moos, D.B.; Peska, P.; Ward, C.D.; Wiprut, D.J. Determination of stress orientation andmagnitude in deepwells. Int. J. Rock Mech. Min. Sci. 2003, 40, 1049-1076. [CrossRef]

5. Slatt, R.; Abousleiman, Y. Merging sequence stratigraphy and geomechanics for unconventional gas shales. Lead. Edge 2011, 30, 274-282. [CrossRef]

6. Ahmed, M.; Rezaei-Gomari, S. Economic Feasibility Analysis of Shale Gas Extraction from UK's Carboniferous Bowland-Hodder Shale Unit. Resources 2019, 8, 5. [CrossRef]

7. Jarvie, D.M.; Hill, R.J.; Ruble, T.E.; Pollastro, R.M. Unconventional shale-gas systems: The Mississippian Barnett Shale of north central Texas as one model for thermogenic shale-gas assessment. AAPG Bull. 2007, 91, 475-499. [CrossRef]

8. Søreide, O.K.; Bostrøm, B.; Horsrud, P. Borehole stability simulations of an HPHT field using anisotropic shale modeling. In Proceedings of the ARMA Conference, Asheville, NC, USA, 28 June-1 July 2008.

9. Slatt, R.; Rodriguez, N. Comparative sequence stratigraphy and organic geochemistry of North American unconventional gas shales: Commonality or coincidence? J. Nat. Gas Sci. Eng. 2012, 8, 68-84. [CrossRef]

10. Lora, R.V.; Ghazanfari, E.; Izquierdo, E.A. Geomechanical characterization of Marcellus shale. Rock Mech. Rock Eng. 2016, 49, 3403-3424. [CrossRef]

11. Buscarnera, G.; Cusatis, G.; Zubelewicz, A.; Bažant, Z.P. Shale fracturing for energy recovery: Current issues and review of available analytical and computational models. Shale Energy Eng. 2014, 168-179. [CrossRef]

12. Sone, H.; Zoback, M.D. Mechanical properties of shale-gas reservoir rocks-Part 1: Static and dynamic elastic properties and anisotropy. Geophysics 2013, 78, 381-392. [CrossRef]

13. Sone, H.; Zoback, M.D. Mechanical properties of shale-gas reservoir rocks-Part 2: Ductile creep, brittle strength, and their relation to the elastic modulus. Geophysics 2013, 78, 393-402. [CrossRef]

14. Johri, M.; Zoback, M.D. The evolution of stimulated reservoir volume during hydraulic stimulation of shale gas formations. In Proceedings of the Unconventional Resources Technology Conference, Society of Exploration Geophysicists, American Association of Petroleum Geologists, Society of Petroleum Engineers, Denver, CO, USA, 12-14 August 2013; pp. 1661-1671.

15. Rybacki, E.; Reinicke, A.; Meier, T.; Makasi, M.; Dresen, G. What controls the mechanical properties of shale rocks?-Part I: Strength and Young's modulus. J. Pet. Sci. Eng. 2015, 135, 702-722. [CrossRef]

16. Feng, X.T. Laboratory and Field Testing. In Rock Mechanics and Engineering; CRC Press: Boca Raton, FL, USA, 2017; Volume 2, pp. 1-646. [CrossRef]

17. Montgomery, C.T.; Smith, M.B. Hydraulic fracturing: History of an enduring technology. J. Petrol. Technol. 2010, 62, 26-40. [CrossRef]

18. Vermylen, J.P. Geomechanical Studies of the Barnett Shale, Texas, USA; Stanford University: Stanford, CA, USA, 2011.

19. Ghassemi, A.; Suarez-Rivera, R. Sustaining Fracture Area and Conductivity of Gas Shale Reservoirs for Enhancing Long-term Production and Recovery. In Proceedings of the AGU Fall Meeting Abstracts, San Francisco, CA, USA, 13-17 December 2010; Volume 2010.

20. Pireh, A.; Alavi, S.A.; Ghassemi, M.R.; Shaban, A. Analysis of natural fractures and effect of deformation intensity on fracture density in Garau formation for shale gas development within two anticlines of Zagros fold and thrust belt. Iran. J. Petrol. Sci. Eng. 2015, 125, 162-180. [CrossRef]

21. Parvizi, H.; Rezaei-Gomari, S.; Nabhani, F.; Dehghan Monfared, A. Modeling the Risk of Commercial Failure for Hydraulic Fracturing Projects Due to Reservoir Heterogeneity. Energies 2018, 11, 218. [CrossRef]

22. Fjær, E.; Holt, A.M.; Horsrud, P.; Raaen, A.M.; Risnes, R. Petroleum Related Rock Mechanics, 2nd ed.; Elsevier: Amsterdam, The Netherlands, 2008.

23. Gholami, R.; Moradzadeh, A.; Rasouli, V.; Hanachi, J. Practical application of failure criteria in determining safe mud weight windows in drilling operations. J. Rock Mech. Geotech. Eng. 2014, 6, 13-25. [CrossRef]

24. Masoud, A.; Abbas, K.M.; Hossein, J. Determination of a safe mud window and analysis of wellbore stability to minimize drilling challenges and non-productive time. J. Pet. Explor. Prod. Technol. 2016, 6, 493-503.

25. Warpinski, N.R.; Mayerhofer, M.J.; Vincent, M.C.; Cipolla, C.L.; Lolon, E.P. Stimulating Unconventional Reservoirs: Maximizing Network Growth While Optimizing Fracture Conductivity. J. Can. Pet. Technol. 2009, 48, 39-51. [CrossRef]

26. Soliman, M.Y.; Daal, J.; East, L. Fracturing unconventional formations to enhance productivity. J. Nat. Gas Sci. Eng. 2012, 8, 52-67. [CrossRef]

27. Islam, M.A.; Skalle, P. An experimental investigation of shale mechanical properties through drained and undrained test mechanisms. Rock Mech. Rock Eng. 2013, 46, 1391-1413. [CrossRef]

28. Meier, T.; Rybacki, E.; Reinicke, A.; Dresen, G. Influence of borehole diameter on the formation of borehole breakouts in black shale. Int. J. Rock Mech. Min. Sci. 2013, 62, 74-85. [CrossRef] 
29. Meier, T.; Rybacki, E.; Backers, T.; Dresen, G. Influence of Bedding Angle on Borehole Stability: A Laboratory Investigation of Transverse Isotropic Oil Shale. Rock Mech. Rock Eng. 2015, 48, 1535-1546. [CrossRef]

30. Han, H.; Yin, S. Determination of in-situ stress and geomechanical properties from borehole deformation. Energies 2018, 11, 113. [CrossRef]

31. Hornby, B.E.; Schwartz, M.L.; Hudson, A.J. Anisotropic effective-medium modeling of the elastic properties of shales. Geophysics 1994, 59, 1570-1583. [CrossRef]

32. Johnston, J.E.; Christensen, N.J. Seismic anisotropy of shales. J. Geophys. Res. 1995, 100, 5991-6003. [CrossRef]

33. Sondergeld, C.H.; Rai, C.S. Elastic anisotropy of shales. Lead. Edge 2011, 30, 324-331. [CrossRef]

34. Vernik, L.; Nur, A. Ultrasonic velocity and anisotropy of hydrocarbon source rocks. Geophysics 1992, 57, 727-735. [CrossRef]

35. Vernik, L.; Liu, X. Velocity anisotropy in shales: A petrophyscial study. Geophysics 1997, 62, 521-532. [CrossRef]

36. Sondergeld, C.H.; Rai, C.S.; Margesson, R.W.; Whidden, K.J. Ultrasonic measurement of anisotropy on the Kimmeridge shale. In Proceedings of the 70th Annual International Meeting, SEG, Expanded Abstracts, Lisbon, Portugal, 15-17 July 2000; pp. 1858-1861.

37. Vernik, L.; Milovac, J. Rock physics of organic shales. Lead. Edge 2011, 30, 318-323. [CrossRef]

38. Vanorio, T.; Mukerji, T.; Mavko, G. Emerging methodologies to characterize the rock physics properties of organic-rich shales. Lead. Edge 2008, 27, 780-787. [CrossRef]

39. Ahmadov, R. Micro-Textural, Elastic and Transport Properties of Source Rocks. Ph.D. Thesis, Stanford University, Stanford, CA, USA, 2011.

40. Josh, M.; Esteban, L.; Delle Piane, C.; Sarout, J.; Dewhurst, D.N.; Clennell, M.B. Laboratory characterisation of shale properties. J. Pet. Sci. Eng. 2012, 88, 107-124. [CrossRef]

41. Dewhurst, D.N.; Siggins, A.F. Impact of fabric, microcracks and stress field on shale anisotropy. Geophys. J. Int. 2006, 165, 135-148. [CrossRef]

42. Sarout, J.; Guéguen, Y. Anisotropy of elastic wave velocities in deformed shales: Part 1-Experimental results. Geophysics 2008, 73, 75-89. [CrossRef]

43. Dewhurst, D.N.; Siggins, A.F.; Sarout, J.; Raven, M.D.; Nordgård-Bolås, H.M. Geomechanical and ultrasonic characterization of a Norwegian Sea shale. Geophysics 2011, 76, 101-111. [CrossRef]

44. Kuila, U.; Dewhurst, D.N.; Siggins, A.F.; Raven, M.D. Stress anisotropy and velocity anisotropy in low porosity shale. Tectonophysics 2011, 503, 34-44. [CrossRef]

45. Hornby, B.E. Experimental laboratory determination of the dynamic elastic properties of wet, drained shales. J. Geophys. Res. 1998, 103, 29945-29964. [CrossRef]

46. Moska, R.; Kasza, P.; Masłowski, M. Rock anisotropy and brittleness from laboratory ultrasonic measurements in the service of hydraulic fracturing. Acta Geodyn. Geromater. 2018, 15, 67-77. [CrossRef]

47. Trzeciak, M.; Sone, H.; Dabrowski, M. Long-term creep tests and viscoelastic constitutive modeling of lower Paleozoic shales from the Baltic Basin, N Poland. Int. J. Rock Mech. Min. Sci. 2018, 112, 139-157. [CrossRef]

48. Rybacki, E.; Meier, T.; Dresen, G. What controls the mechanical properties of shale rocks?-Part II: Brittleness. J. Pet. Sci. Eng. 2016, 144, 39-58. [CrossRef]

49. Warpinski, N.R.; Waltman, C.K.; Du, J.; Ma, Q. Anisotropy effects in microseismic monitoring. In Proceedings of the SPE Annual Technical Conference and Exhibition, New Orleans, LO, USA, 4-7 October 2009. [CrossRef]

50. Bayuk, I.O.; Chesnokov, E.; Ammerman, M. Why anisotropy is important for location of microearthquake events in shale? In Proceedings of the Extended Abstract for 79th SEG Annual Conference, Houston, TX, USA, 25-30 October 2009; pp. $1632-1636$.

51. Grechka, V.; Singh, P.; Das, I. Estimation of effective anisotropy simultaneously with locations of microseismic events. Geophysics 2011, 76, 143-155. [CrossRef]

52. Grechka, V.; Yaskevich, S. Azimuthal anisotropy in microseismic monitoring: A Bakken case study. Geophysics 2014, 79, 1-12. [CrossRef]

53. Gajek, W.; Trojanowski, J.; Malinowski, M.; Jarosiński, M.; Riedel, M. Results of the downhole microseismic monitoring at a pilot hydraulic fracturing site in Poland-Part 1: Event location and stimulation performance. Interpretation 2018, 6, 39-48. [CrossRef]

54. Dyrka, I. Petrophysical and mineralogical characterization of prospective hydrocarbon complexes estimated based on selected laboratory research results. Przeglad Geol. 2016, 64, 982-986.

55. Karcz, P.; Janas, M. Organic matter in Cambrian, Ordovician and Silurian shales of the Baltic-Podlasie-Lublin Basin in Poland. Przeglad Geol. 2016, 64, 995-999.

56. Podhalańska, T.; Waksmundzka, M.I.; Becker, A.; Roszkowska-Remin, J.; Dyrka, I.; Feldman-Olszewska, A.; Głuszyński, A.; Grotek, I.; Janas, M.; Karcz, P.; et al. Prospective zones for unconventional hydrocarbon resources in Cambrian, Ordovician, Silurian and Carboniferous rocks of Poland: Integration of the research results. Przeglad Geol. 2016, 64, $1008-1021$.

57. Sowiżdżał, K.; Such, P.; Leśniak, G.; Słota-Valim, M. Evaluation of the impact of the petrophysical properties of shale formations on their sealing efficiency for underburden reservoir intervals and hydrocarbon accumulations. Nafta-Gaz 2017, 73, 730-738. [CrossRef]

58. Such, P.; Leśniak, G.; Mroczkowska-Szerszeń, M.; Dudek, L.; Cicha-Szot, R.; Spunda, K. Methodology of pore space analysis in shale rocks. Pract. Nauk. Inst. Naft. Gazu 2017, 214, 1-154. 
59. Hossain, M.M.; Rahman, M.K.; Rahman, S.S. Hydraulic fracture initiation and propagation: Roles of wellbore trajectory, perforation and stress regimes. J. Petrol. Sci. Eng. 2000, 27, 129-149. [CrossRef]

60. Davies, R.J.; Mathias, S.A.; Moss, J.; Hustoft, S.; Newport, L. Hydraulic fractures: How far can they go? Mar. Petrol. Geol. 2012, 37, 1-6. [CrossRef]

61. Ghassemi, A.; Zhou, X.X.; Rawal, C. A three-dimensional poroelastic analysis of rock failure around a hydraulic fracture. J. Petrol. Sci. Eng. 2013, 108, 118-127. [CrossRef]

62. Rezaee, R. Fundamentals of Gas Shale Reservoirs; John Wiley \& Sons: Hoboken, NJ, USA, 2015.

63. Kasza, P. Hydraulic fracturing in unconventional reservoirs, and methods of their analysis. Pract. Nauk. Inst. Naft. Gazu 2019, 226, 1-147. [CrossRef]

64. Wilk, K. Experimental and Simulation Studies of Energized Fracturing Fluid Efficiency in Tight Gas Formations. Energies 2019, 12, 4465. [CrossRef]

65. Li, Q.; Xinga, H.; Liu, J.; Liu, X. A review on hydraulic fracturing of unconventional reservoir. Petroleum 2015, 1, 8-15. [CrossRef]

66. Becklumb, P.; Williams, T.G.; Chong, J. Shale Gas in Canada: Environmental Risks and Regulation; Library of Parliament-Bibliothèque Du Parlement, Economics, Resources and International Affairs Division, Resources and International Affairs Division Parliament of Canada: Ottawa, CA, Canada, 2015; Volume 18.

67. Howarth, R.W.; Santoro, R.; Ingraffea, A. Methane and the greenhouse-gas footprint of natural gas from shale formations. Clim. Change 2011, 106, 679. [CrossRef]

68. Mahesar, A.A.; Shar, A.M.; Ali, M.; Tunio, A.H.; Uqailli, M.A.; Mohanty, U.S.; Akhondzadeh, H.; Iglauer, S.; Keshavarz, A. Morphological and petro physical estimation of Eocene tight carbonate formation cracking by cryogenic liquid nitrogen; a case study of Lower Indus basin, Pakistan. J. Pet. Sci. Eng. 2020, 192, 107318. [CrossRef]

69. Memon, K.R.; Mahesar, A.A.; Ali, M.; Tunio, A.H.; Mohanty, U.S.; Akhondzadeh, H.; Awan, F.U.R.; Iglauer, S.; Keshavarz, A. Influence of Cryogenic Liquid Nitrogen on Petro-Physical Characteristics of Mancos Shale: An Experimental Investigation. Energy Fuels 2020, 34, 2160-2168. [CrossRef]

70. Poprawa, P.; Šliaupa, S.; Stephenson, R.; Lazauskien, J. Late Vendian-Early Palæozoic tectonic evolution of the Baltic Basin: Regional tectonic implications from subsidence analysis. Tectonophysics 1999, 314, 219-239. [CrossRef]

71. Poprawa, P. Shale gas potential of the Lower Palaeozoic complex in the Baltic and Lublin-Podlasie basins (Poland). Przeglad Geol. 2010, 58, 226-249.

72. Modliński, Z.; Podhalańska, T. Outline of the lithology and depositional features of the lower Paleozoic strata in the Polish part of the Baltic region. Geol. Q. 2010, 54, 109-121.

73. Rietveld, H.M. A profile refinement method for nuclear and magnetic structures. J. Appl. Crystallogr. 1969, 2, 65-71. [CrossRef]

74. Leśniak, G.; Sowiżdżał, K.; Stadtmuller, M.; Lis-Śledziona, A.; Kaczmarczyk, W.; Słota-Valim, M.; Kasza, P. Wykonanie niestandardowych Kompleksowych Badań Petrofizycznych i Geomechanicznych na Próbkach i Danych z Dolnopaleozoicznych Łupków; Technical Report, Shalemech no. 3; INiG-PIB: Kraków, Poland, 2017.

75. Janas, M. Rock-Eval Study on Samples Dedicated to ShaleMech Geomechanical Tests (Samples from O-3, B-1, W-1 and M-1 Wells). 2017; Unpublished Report.

76. ASTM D 4543-01. Standard Practices for Preparing Rock Core Specimens and Determining Dimensional and Shape Tolerances. Annual Book of ASTM Standards; ASTM International: West Conshohocken, PA, USA, 2001.

77. Bieniawski, Z.T.; Bernede, M.J. Suggested methods for determining the uniaxial compressive strength and deformability of rock materials: Part 1. Suggested method for determining deformability of rock materials in uniaxial compression. Int. J. Rock Mech. Min. Sci. Geomech. Abstr. 1979, 16, 138-140. [CrossRef]

78. ASTM D 2664-95a. Standard Test Method for Triaxial Compressive Strength of Undrained Rock Core Specimens Without Pore Pressure Measurements; ASTM International: West Conshohocken, PA, USA, 1995.

79. Eurokod 7-PN-EN-1997-2:2009. Geotechnical Design. Design Assisted by Laboratory Testing; European Committee for Standardization: Brussel, Belgium, 2009.

80. Hallbauer, D.K.; Wagner, H.; Cook, N.G.W. Some observations concerning the microscopic and mechanical behavior of quartzite specimens in stiff, triaxial compression tests. Int. J. Rock Mech. Min. Sci. 1973, 10, 713-726. [CrossRef]

81. ASTM D 3148-02. Standard Test Method for Elastic Moduli of Intact Rock Core Specimens in Uniaxial Compression; ASTM International: West Conshohocken, PA, USA, 1993.

82. Dohnalik, M.; Kowalska, S.; Mikołajewski, Z.; Domonik, A.; Tabor, Z. Mineral composition of shales and the results of triaxial compression tests-A case study from the Ordovician and Silurian rocks of Poland. Nafta-Gaz 2015, 71, 355-360.

83. Niandou, H.; Shao, J.F.; Henry, J.P.; Fourmaintraux, D. Laboratory investigation of the mechanical behavior of Tournemire shale. Int. J. Rock Mech. Min. Sci. 1997, 34, 3-16. [CrossRef] 